\title{
First report of yellow leaf spot caused by Corynespora cassiicola on giloy in India
}

\author{
Ram Prasnna Meena ${ }^{1}\left[\right.$ (D) Vasudha A. Kadam ${ }^{1} \cdot$ Goutam Mondal $^{2}$. Satyajit Roy ${ }^{1}$
}

Received: 4 August 2020 / Accepted: 14 October 2021 / Published online: 25 October 2021

(c) Società Italiana di Patologia Vegetale (S.I.Pa.V.) 2021

Keywords Corynespora $\cdot$ Conidiophores $\cdot$ Internal transcribed spacer $\cdot$ Necrotic spot

During the years 2015-16 in August-September months, yellow spot symptoms on giloy (Tinospora cordifolia) were observed at ICAR-DMAPR, Anand, Gujarat. Initial infection showed minute yellow spots on upper surface and discolouration on the corresponding lower surface of leaves. Then the spots coalesced and turned into chlorotic and brownish necrotic spots, and lead to premature defoliation. The fungal structures aggregated as whitish to greyish powdery masses at the lower surface of the leaves. Infected leaves were surface sterilized with $1 \%$ sodium hypochlorite $(\mathrm{NaOCl})$ for $2 \mathrm{~min}$, rinsed in sterile distilled water twice and dried with sterilized paper. Small bits of infected leaves were placed on potato dextrose agar (PDA) and incubated at $25 \pm 2{ }^{\circ} \mathrm{C}$ for $7-8$ days. The fungal colonies effused greyish to blackish tinge with hyaline, septate, simple flexuous conidiophores, aroused in clusters from the upper cells of stroma of 50-208 $\times 6-12 \mu \mathrm{m}$ with distinct but thin scars. Conidia were hyaline, straight to slightly curved, obclavate with truncate to thick ended base, $128.42 \mu \mathrm{m}$ ( 25 to 242 ) in length and $17.74 \mu \mathrm{m}$ ( 7 to $21 \mu \mathrm{m})$ in width with different shape, typically, as of Corynespora cassiicola (Fulmer et al. 2012). Further, the internal transcribed spacer (ITS) region was amplified using the ITS1/ITS4 primers (White et al. 1990). The sequences from the fungus (isolate ATC-1), showed $>99 \%$ identity with homologue region of Corynespora cassiicola (MG976659.1, KU593529.1, etc.), submitted in NCBI GenBank under accession No. MK027366.1. To establish the pathogenicity, a 10-day-old culture was used for preparation of inoculum suspension, sprayed on three mature leaves and replicated thrice along with control, sprayed with sterilized water. The plants were

Ram Prasnna Meena

rp.meena@icar.gov.in

1 ICAR-Directorate of Medicinal and Aromatic Plants Research, Anand, Gujarat 387310, India

2 Bidhan Chandra Krishi Viswavidhyalaya, Haringhata, West Bengal 741235, India kept separately at $25 \pm 5^{\circ} \mathrm{C}$ in the customized humid chambers for initial $48 \mathrm{~h}$. After 10-12 days of the inoculation, developed symptoms were similar to those of naturally infected plants. Further, re-isolation of identical pathogen was established from the inoculated plants. Earlier, Corynespora calicioidae had been reported on giloy in India (Kapoor and Munjal 1968); however, to the best of our knowledge, this is the first report of C. cassiicola causing yellow leaf spot disease of giloy.

Funding The author (s) received the financial support from its institutional research grant of ICAR- DMAPR, Anand for the research work.

\section{Declarations}

Ethical approval This article does not contain any studies with human participants or animals performed by any of the authors.

Conflict of interest The authors declare that they have no conflict of interest about this manuscript and research.

\section{References}

Fulmer AM, Walls JT, Dutta B, Parkunan V, Brock J, Kemerait RC Jr (2012) First Report of Target Spot Caused by Corynespora cassiicola on Cotton in Georgia. Plant Dis 96(7):1066

Kapoor JN, Munjal RB (1968) Addition to Indian Fungi. Indian Phytopath 21:107-112

White TJ, Bruns T, Lee SJWT, Taylor JW (1990) Amplification and direct sequencing of fungal ribosomal RNA genes for phylogenetics. In: PCR Protocols; A Guide to Methods and Applications. Academic Press, New York, pp 315-322

Publisher's Note Springer Nature remains neutral with regard to jurisdictional claims in published maps and institutional affiliations. 